\title{
The Influence of Human Motivation Factors on the Successful Implementation of Product Life Cycle Management Tools: Explorative Findings and Managerial Implications
}

\author{
Bernd Markus Zunk ${ }^{1}$, Julia Soos ${ }^{1}$, Iris Uitz ${ }^{1}$, Andrea Denger ${ }^{2}$, Michael Bader ${ }^{3}$ \\ ${ }^{1}$ Graz University of Technology, Institute of Business Economics and Industrial Sociology, Kopernikusgasse 24/II, Graz, \\ Austria, bernd.zunk@tugraz.at (corresponding) \\ ${ }^{2}$ Virtual Vehicle Research Center, Inffeldgasse 21a/I, Graz, Austria \\ ${ }^{3}$ Graz University of Technology, Institute of Machine Components and Methods of Development, Inffeldgasse 21b/II, \\ Austria
}

For technology firms it is crucial to integrate progressive product design methods such as Product Lifecycle Management (PLM) tools in their daily routines to improve the quality of the product development process. However, in practice one problem arises: research and development $(R \& D)$ employees show little motivation to implement these tools in their work. This paper aims at determining human factors for successful implementation of PLM by studying the motivation of R\&D employees. Based on a literature study, face-to-face interviews with 16 R\&D experts were performed. Furthermore, a survey study with 22 participants using online questionnaires was conducted. Based on the results of the data analysis, a list of critical human success factors which help managers to implement PLM tools in R\&D departments of technology firms successfully is presented.

Keywords: product lifecycle management tools, human factors, motivation, research and development

\section{Acknowledgements}

The authors wish to acknowledge the support of the cooperation partner Virtual Vehicle Research Center (VIF), especially Mr. Alexander Mastnak for helping us during the data collection phase of this research project. Furthermore, the authors would like to acknowledge the helpful comments of the reviewers on an earlier version of this paper, originally presented at the 5th International MOTSP Conference in Novi Vinodolski, Croatia, from 29 to 31 May 2013.

\section{References}

[1] KIRITSIS, D., BUFARDI, A., XIROUCHAKIS, P. (2003). Research issues on product lifecycle management and information tracking using smart embedded systems. In: Advanced Engineering Informatics, Vol. 17, No. 3/4, pp. $189-202$.

[2] EIGNER, M., STELZER, R. (2009). Product Lifecycle Management: Ein Leitfaden für Product Development und Life Cycle Management, Springer, Berlin.

[3] ABRAMOVICI, M. (2007). Future trends in product lifecycle management (PLM). The Future of Product Development, Part 12, Springer, Berlin.

[4] SENDLER, U. (2009). Das PLM-Kompendium, Springer, München.

[5] SCHMEJA, M., DENGER, A. (2011). Future PLM - Ansätze für ein mitarbeiterzentriertes PLM. In: Proceedings of Product Life live, Stuttgart, pp. 129 - 136.

[6] LAMPELA, H.; DENGER, A.; KÄRKKÄINEN, H.; ZOIER, M. (2011). Future of Collaboration in Managing Product Lifecycle Information and Knowledge. In: Proceedings of EBRF 11 (Research Forum to Understand Business in Knowledge Society), Espoo, pp. 217 - 230.

[7] DENGER, A.; SCHMEJA, M.; UNZEITIG, W.; SCHLÜTER, W.; PESCHKE, F. (2011). Product Lifecycle Management (PLM). Ein Blick auf den Mitarbeiter von morgen. In: ProduktDaten Journal, Vol. 18, No. 2, pp. 55 59.

[8] DENGER, A.; STOCKER, A.; SCHMEJA, M. (2012). Future Workplace: Eine Untersuchung sozio-technischer Einflüsse auf den Arbeitsplatz der Zukunft, Aachen.

[9] ABRAMOVICI, M. (2010). Benefits of PLM in der Automobilindustrie, Benchmarkstudie 2009. In: Proceedings Product Life live 2010, Berlin, pp. 170 - 186.

[10] WISWEDE, G. (2007). Einführung in die Wirtschaftspsychologie, Reinhardt, München.

[11] LAUER, T. (2010): Change Management. Grundlagen und Erfolgsfaktoren, Springer, Heidelberg.

[12] PINTO, J., PRESCOTT, J. (1988). Variations in critical success factors over the stages in the project life cycle. In: Journal of Management, Vol. 14, No.1, pp. 5 - 18.

[13] PINTO, J., SLEVIN, D. (1987). Critical factors in successful project implementation. In: IEEE Transactions on Engineering Management, Vol. 34, No. 1, pp. 22 - 27.

[14] GREIF, S., RUNDE, B., SEEBERG, I. (2004). Erfolge und Misserfolge beim Change Management, Hogrefe, Göttingen. 
[15] WATERIDGE, J. (1995). IT projects: a basis for success. In: International Journal of Project Management, Vol. 13, No. 3, pp. 169-172.

[16] MOHR, N. (1997). Kommunikation und organisatorischer Wandel, Gabler, Wiesbaden.

[17] BELASSI, W., TIKEL, O. (1996). A new framework for determining critical success/failure factors in projects. In: International Journal of Project Management, Vol. 14, No. 3, pp. 141 - 151.

[18] JOST, P.-J. (2000). Organisation und Motivation, Gabler, Wiesbaden.

[19] WILEY, C. (1997). What motivates employees according to over 40 years of motivation surveys. In: International Journal of Manpower, Vol. 18, No. 3, pp. 263 - 280.

[20] Virtual Vehicle Research Center (2011): Interviewstudie: Erfolgsparameter bei der Einführung von PLM, Graz.

[21] ZUNK, B. M.; MARCHNER, A. (2009): Verbesserung der Produktion zwischen Beschaffung und Produktentwicklung, In: Zeitschrift für wirtschaftichen Fabrikbetrieb, Vol. 12, No. 11/12, pp. 1087 - 1092.

[22] LEAVITT, R. (2012). Delivering on the Promise: Key Success Factors for PLM Strategy, Implementation and Adoption, PPL0612.pdf.

[23] THITE, M. (2000). Leadership styles in information technology projects. In: International Journal of Project Management, Vol. 18, No. 4, pp. 235 - 241.

[24] WILLIAMSON, O. (1996). Transaktionskostenökonomik, LIT, Hamburg.

[25] ABRAMOVICI, M.; SCHULTE, S.; LESZINSKI, C. (2005). Best Practice Strategien für die Einführung von Product Lifecycle Management, GITO, Berlin.

[26] MASTNAK, A. (2012). Human Critical Success Parameters at the implementation of Product Lifecycle Management (PLM), Master Thesis, Graz University of Technology, Graz.

[27] ZUNK, B. M.; SOOS, J.; DENGER, A.; UITZ, I.; SCHMEJA, M. (2013). Human Factors Influencing the Success of the Implementation of Product Life Cycle Management Tools in Technology Firms. In: Proceedings of the 5th International MOTSP Conference, pp. $102-110$. 